\title{
Long-term potentiation can be induced in the CAI region of hippocampus in the absence of $\alpha$ CaMKII T286-autophosphorylation
}

\author{
Agnès Villers, ${ }^{1}$ Karl Peter Giese, ${ }^{2}$ and Laurence Ris ${ }^{1}$ \\ ${ }^{1}$ Department of Neuroscience, Research Institute for Biosciences, University of Mons, B-7000 Mons, Belgium; ${ }^{2}$ MRC Centre \\ for Neurodegeneration, Institute of Psychiatry, King's College London, SE5 9NU, London, United Kingdom
}

\begin{abstract}
$\alpha$-calcium/calmodulin-dependent protein kinase ( $\alpha$ CaMKII) T286-autophosphorylation provides a short-term molecular memory that was thought to be required for LTP and for learning and memory. However, it has been shown that learning can occur in $\alpha$ CaMKII-T286A mutant mice after a massed training protocol. This raises the question of whether there might be a form of LTP in these mice that can occur without T286 autophosphorylation. In this study, we confirmed that in CAl pyramidal cells, LTP induced in acute hippocampal slices, after a recovery period in an interface chamber, is strictly dependent on postsynaptic $\alpha \mathrm{CaMKII}$ autophosphorylation. However, we demonstrated that $\alpha \mathrm{CaMKII-autophosphorylation-inde-}$ pendent plasticity can occur in the hippocampus but at the expense of synaptic specificity. This nonspecific LTP was observed in mutant and wild-type mice after a recovery period in a submersion chamber and was independent of NMDA receptors. Moreover, when slices prepared from mutant mice were preincubated during $2 \mathrm{~h}$ with rapamycin, high-frequency trains induced a synapse-specific LTP which was added to the nonspecific LTP. This specific LTP was related to an increase in the duration and the amplitude of NMDA receptor-mediated response induced by rapamycin.
\end{abstract}

The formation of memories is believed to be achieved through strengthening of synaptic communication between two simultaneously active neurons, a phenomenon called long-term potentiation (LTP). For several years, numerous studies have sought to better understand the molecular mechanisms of synaptic plasticity and LTP, and in particular the role of calcium-calmodulin-dependent protein kinase II (CaMKII), one of the most important postsynaptic components in glutamatergic synapses. Indeed, CaMKII is both necessary and sufficient for LTP induction. The application of CaMKII inhibitors, such as KN-62 or KN-93, or genetic disruption of the CaMKII gene can block LTP (Malinow et al. 1989; Otmakhov et al. 1997; Hinds et al. 1998; Yamagata et al. 2009). Conversely, the injection or viral expression of a constitutively active form of CaMKII leads to the improvement of spatial memory (Poulsen et al. 2007), in enhancement of AMPAR-mediated synaptic transmission and occludes further induction of LTP (McGladeMcCulloh et al. 1993; Pettit et al. 1994; Lledo et al. 1995). This enhancement in AMPAR conductance has been proposed to occur through an increase in synaptic trafficking of GluA1 subunits, as well as phosphorylation of GluA1 at Ser831 (Shi et al. 1999; Hayashi et al. 2000; Broutman and Baudry 2001; Esteban et al. 2003; Oh et al. 2006). Besides its role in synaptic transmission, CaMKII is also involved in the structural plasticity of spines, and more specifically in activity-dependent spine growth following NMDAR activation (Okamoto et al. 2009; Pi et al. 2010). Moreover, it seems that CaMKII-dependent processes involved in hippocampal LTP in CA1 synapses are quite general since the kinase also affects in vivo plasticity in different brain regions (Wu and Cline 1998; Zou and Cline 1999). Disruption of CaMKII activation leads to developmental changes in synaptic function and affects experience-dependent plasticity and behavioral memory (Silva et al. 1992a,b; Glazewski et al. 1996, 2000). In addition, the homologous kinase in invertebrates plays a key role in synap-

Corresponding author: laurence.ris@umons.ac.be Article is online at http://www.learnmem.org/cgi/doi/10.1101/lm.035972.114. tic function and learning, suggesting an early evolutionary origin of CaMKII in information storage (Griffith et al. 1993; Koh et al. 1999).

The CaMKII family consists of 28 isoforms, derived from four genes $(\alpha, \beta, \gamma$, and $\delta)$, but the $\alpha$ and $\beta$ subunits are predominant in the brain (Erondu and Kennedy 1985; Schulman and Hanson 1993; Ochiishi et al. 1998; Li et al. 2001). Each isoform comprises a catalytic domain, containing the ATP- and substrate-binding sites, an autoinhibitory domain, and a self-association domain. The latter enables the formation of a dodecameric holoenzyme containing either one or both subunit types. In basal conditions, the catalytic domain, responsible for the phosphotransferase reaction, is inhibited by the autoinhibitory domain of the same subunit, which is acting like a gate (Coultrap and Bayer 2012; Lisman et al. 2012). When the calcium concentration rises, the calcium/ calmodulin complex subsequently formed can bind to the autoinhibitory domain, enabling the gate to open and thus the substrate to access its binding site (Morris and Török 2001; Hudmon and Schulman 2002; Rellos et al. 2010; Chao et al. 2011). Another consequence of this opening is the exposure of a particular amino acid, Thr286, on the $\alpha$ subunit (Thr287 for the $\beta$ subunit), located in the autoinhibitory domain. Once this site is phosphorylated by a neighboring subunit, the dissociation of calmodulin is highly reduced (Meyer et al. 1992). Moreover, the gate cannot close even after dissociation of the calcium/calmodulin complex, making the enzyme autonomous, with a calcium-independent activity (Rich and Schulman 1998; Hoffman et al. 2011).

Following calcium elevation, CaMKII diffuses to the synapse and accumulates in the postsynaptic density (PSD), where it binds to NMDA receptors through the carboxy-terminal domain of the

\footnotetext{
(C) 2014 Villers et al. This article is distributed exclusively by Cold Spring Harbor Laboratory Press for the first 12 months after the full-issue publication date (see http://learnmem.cshlp.org/site/misc/terms.xhtml). After 12 months, it is available under a Creative Commons License (Attribution-NonCommercial 4.0 International), as described at http://creativecommons.org/ licenses/by-nc/4.0/.
} 
NR2B subunit (Strack and Colbran 1998; Shen and Meyer 1999; Bayer et al. 2001; Leonard et al. 2002). The binding sequence of NR2B blocks the autoinhibitory gate of CaMKII, leaving it in an active state, even after dissociation of the calcium/calmodulin complex and without autophosphorylation. This active state is transient, ranging from seconds to minutes, but is not affected by phosphatase activity, unlike the autonomous activity produced by autophosphorylation (Bayer et al. 2001). Furthermore, the binding of CaMKII to NMDA receptors increases calmodulin affinity for the kinase. This phenomenon, called trapping, may be a way of preventing dissociation of CaMKII from synaptic sites. Indeed, it inhibits the autophosphorylation of a secondary site (Thr 305) which would precisely be responsible for the kinase deactivation and release from synapses (Shen et al. 2000). Besides its functional role, the binding of CaMKII to NMDA receptors has structural consequences as well, as it creates scaffolding for AMPA receptor-binding proteins and allows subsequent incorporation of additional AMPA receptors into the PSD (Lisman and Zhabotinsky 2001; Sanhueza and Lisman 2013). Sanhueza et al. (2011) showed that the CN class of peptides inhibiting CaMKII binding to NR2B reduced basal synaptic transmission and reversed saturated LTP. Halt et al. (2012) generated mice with two-point mutations that impair CaMKII binding to the NR2B subunit and showed that CaMKII/NR2B binding contributes to LTP and that it is required for LTP-induced GluA1 S831 phosphorylation. In the same line of evidence, Barria and Malinow (2005) demonstrated the requirement of CaMKII/NR2B binding for LTP induction.

Using two-photon fluorescence lifetime imaging microscopy, Lee et al. (2009) have shown that CaMKII activation triggered in single spines by glutamate uncaging is rather transient, lasting only $1 \mathrm{~min}$. Similarly, Lengyel et al. (2004) showed that the calcium-independent activity of $\alpha$ CaMKII was increased for only up to 2 min after induction of chemical LTP. However, even though this persistent activity is short-term, it is required for CA1 LTP (Fukunaga et al. 1993; Ouyang et al. 1997; Giese et al. 1998; Buard et al. 2010) and LTD (Coultrap et al. 2014). This autonomous activity extends kinase activity beyond the window of calcium elevation, depending on the dephosphorylation rate of the subunits. Murakoshi et al. (2011) have demonstrated that the transient activation of CaMKII is responsible for persistent activation (more than half an hour) of small GTPases, RhoA and Cdc42. These GTPases are involved in structural plasticity occurring during spine enlargement.

Each of the thousands of synapses that are exhibited by neurons is thought to be independently modifiable by LTP. This synaptic specificity, where only activated synapses become strengthened, leaving neighboring synapses unaffected, is precisely what enables neurons to store huge amounts of data. In this context, CaMKII, thanks to its activation process, is a detector of calcium spikes occurring in the neuron. Hanson et al. (1994) predicted that repetitive calcium pulses would lead to the recruitment of limited calmodulin to the holoenzyme, which would further stimulate autophosphorylation while De Koninck et al. (1998) showed that the enzyme can decode the frequency of $\mathrm{Ca}^{2+}$ spikes into distinct amounts of kinase activity. Hence, a calcium increase compartmentalized in an activated spine would lead to CaMKII activation specifically in that subcellular region (Lee et al. 2009; Lemieux et al. 2012). On the other hand, calcium increases happening through voltage-dependent calcium channels or endoplasmic reticulum release might convey a specific signal supporting the plasticity of neighboring synapses (Greer and Greenberg 2008; Wheeler et al. 2008; Rose et al. 2009).

In this study, we used mice deficient in $\alpha$ CaMKII autophosphorylation due to the T286A mutation (Giese et al. 1998). We showed that the need for autophosphorylation was linked to NMDA receptor activation. NMDA-independent LTP could be in- duced in T286A mice, but in this case, LTP was not restricted to stimulated synapses. This nonspecific LTP was observed in mutant and wild-type mice after a recovery period in submersion. Moreover, when slices prepared from mutant mice were preincubated during $2 \mathrm{~h}$ with rapamycin, an inhibitor of mTOR-dependent translation, high-frequency trains induced a synapse-specific LTP which was added to the nonspecific LTP. We showed that this specific LTP was related to an increase in the duration and the amplitude of NMDA receptor-mediated response induced by rapamycin.

\section{Results}

\section{In CAl pyramidal cells, after a recovery period in submersion, long-lasting LTP can be induced by repeated $100 \mathrm{~Hz}$ trains in T286A mutant mice}

In slices which were allowed to recover in interface (Fig. 1A), four trains at $100 \mathrm{~Hz}$ induced an increase of $>200 \%$ in synaptic strength, but this potentiation could not be maintained over time (Fig. 1C). In WT mice, the same protocol induced a potentiation of $>300 \%$ which was maintained at $200 \%$ during $4 \mathrm{~h}$. This impairment was most probably postsynaptic as synaptic fatigue was not modified (Fig. 1E) in mutant mice compared with WT mice (two-way ANOVA, $F_{(1,19)}=0.21, P=0.65$ ) (Dobrunz and Stevens 1997).

We previously demonstrated that maintaining the slices in submersion after dissection, during the 90-min recovery period, lowered the threshold of LTP and modified its properties (Capron et al. 2006). We therefore wondered whether allowing the slices prepared from T286A mice to recover in submersion (Fig. 1B) could modify LTP properties and make it independent of $\alpha$ CaMKII autophosphorylation.

As shown in Figure 1D, four trains of high-frequency stimulation (HFS), applied after a recovery period in submersion, induced an immediate increase of up to $200 \%$ in synaptic strength, which was further maintained to $138 \pm 5 \%$ after 4 $\mathrm{h}$. Under the same conditions, LTP induced in WT mice was maintained at $235 \pm 22 \%$ during $4 \mathrm{~h}$ (Fig. 1D). Here again, the postsynaptic fatigue observed during the train was not different in mutant and WT mice (Fig. 1F, two-way ANOVA, $F_{(1,13)}=0.50, P=0.49$ ).

\section{LTP induced without $\alpha$ CaMKII autophosphorylation is not specific to stimulated synapses and is independent of NMDA receptors}

When slices prepared from mutant mice or WT mice were allowed to recover in submersion, we observed that the control pathway which was not submitted to HFS presented a slow increase in synaptic strength. In mutant mice, the potentiation of the non-HFstimulated pathway reached $138 \pm 8 \%$ of the baseline at the end of the experiment (Student's $t$-test $P=0.005$, Fig. 2A). If the percentage of potentiation was recalculated considering this increase, which is not synapse-specific, it would produce a curve which is very similar to that observed when the resting period occurred in interface (Fig. 2C cf. Fig. 1C). We checked that the two pathways were independent to be sure that the potentiation observed in the pathway which did not receive the HFS was not due to superposition of the two stimulated axon bundles. When the second pathway was stimulated $50 \mathrm{msec}$ after the first pathway, the slope of the fEPSP did not undergo facilitation (106 \pm $2 \%)$ while paired-pulses applied to the same pathway induced a facilitation of $149 \pm 8 \%(n=7)$.

Under the same conditions, in WT mice, the potentiation of the control pathway reached $156 \pm 14 \%$ of the baseline at the end of the experiment (Student's $t$-test $P=0.017$, Fig. 2B). In this case the nonspecific potentiation is added to the synapse-specific LTP 
A

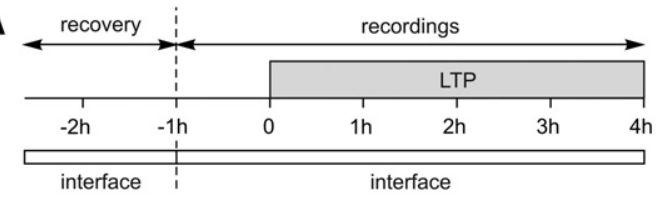

C
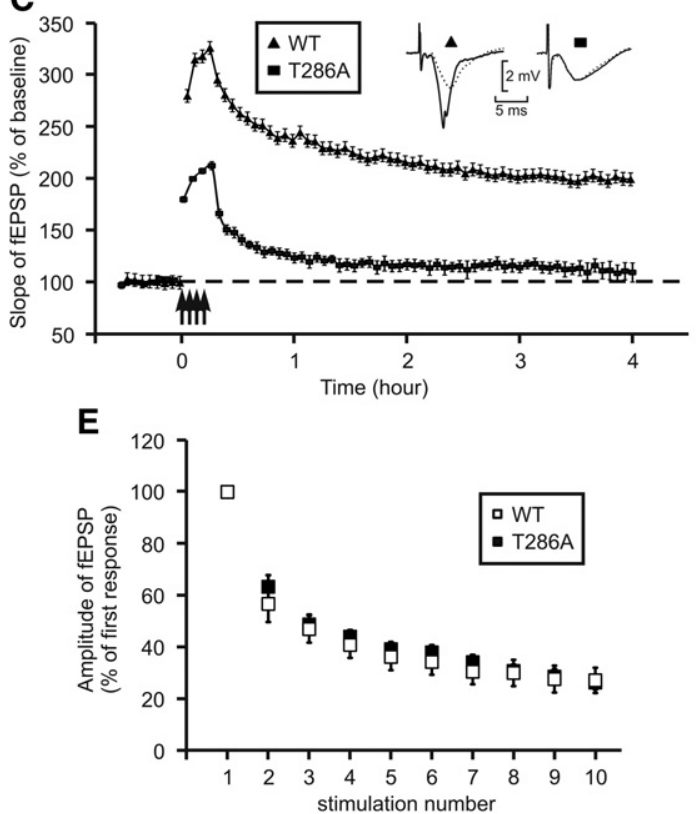

B
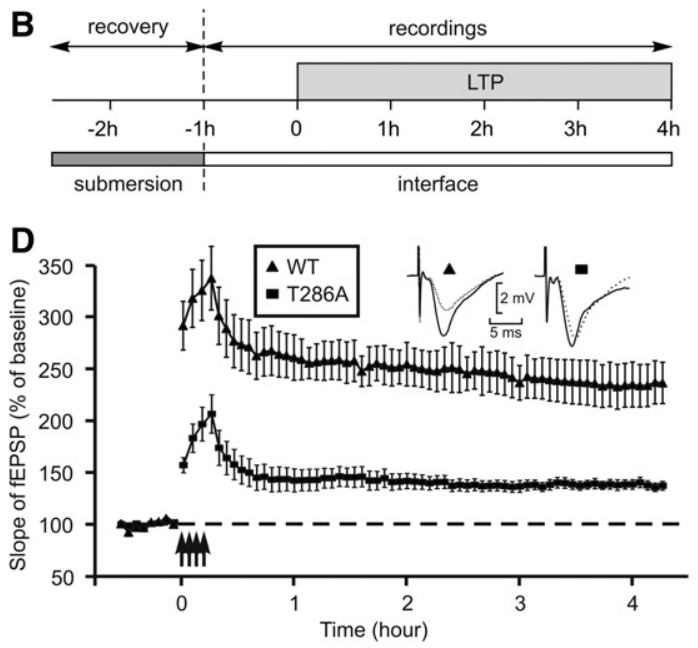

$\mathbf{F}$

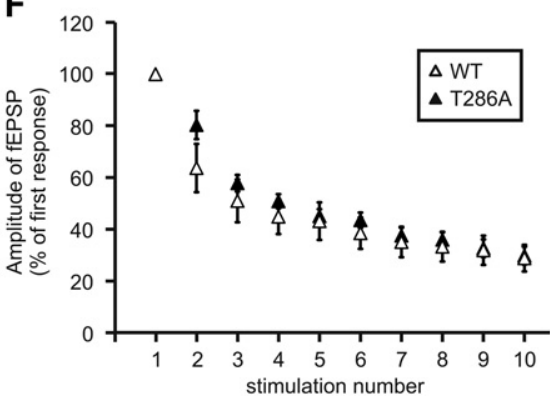

Figure 1. Successful induction of LTP without $\alpha$ CaMKII autophosphorylation is dependent on slice recovery conditions. $(A, B)$ Diagrams of the experimental paradigm, with a recovery period either in interface, $A$, or in submersion, $B$. ( $C, D)$ Time-course of the slope of fEPSP, while LTP was triggered using four trains of high-frequency stimulation (arrows). Insets show fEPSP waveforms, recorded just before LTP induction (dotted trace) or $4 \mathrm{~h}$ afterward (full trace). (C) After a recovery period in interface, on slices from T286A (squares, $n=3$ ) or wild-type (triangles, $n=8$ ) mice. $(D)$ After a recovery period in submersion, on slices from T286A (squares, $n=7$ ) or wild-type (triangles, $n=5$ ) mice. ( $E, F)$ Postsynaptic fatigue during high-frequency stimulation was assessed by the reduction in fEPSP amplitude during the first 10 stimulations of the first train. (E) Following a recovery period in interface, in wild-type (empty squares, $n=6$ ) or T286A (black squares, $n=15$ ) mice. $(F)$ Following a recovery period in submersion, in wild-type (empty triangles, $n=7$ ) or T286A (black triangles, $n=8$ ) mice.

which can be estimated by recalculating the percentage of potentiation without nonspecific response (Fig. 2D). We checked, in control mice, that the slow increase of potentiation observed in the nonstimulated pathway was not due to a slow drift of the response independent of the stimulation. When no trains were induced in any of the two pathways, the basal synaptic responses were stable during $>4 \mathrm{~h}$ (Fig. $2 \mathrm{G}$ ).

We tested whether this nonspecific LTP observed in mutant and WT mice was dependent on NMDA receptor activation. The addition of APV $(50 \mu \mathrm{M})$, an antagonist of NMDA receptors, 30 min before the induction of LTP in mutant mice, reduced the immediate increase in synaptic strength but did not prevent the slow increase observed in both pathways (Fig. 2E). This effect seemed even heightened by the presence of APV, as the potentiation reached $4 \mathrm{~h}$ after the trains was of $171 \pm 14 \%$ instead of $138 \pm$ $5 \%$ without APV (Wilcoxon rank-sum test $P=0.035$ ).

In WT mice, in the presence of APV, the nonspecific LTP reached nearly the same level in the stimulated and the nonstimulated pathways $(193.4 \pm 23.5 \%$ and $162.9 \pm 10.8 \%$, respectively, Fig. 2F). This observed increase was not due to a drift of the response over time because under the same conditions, when no HFS was applied to the slice, the fEPSP slope remained stable for $>4 \mathrm{~h}$ (Fig. 2G). Figure $2 \mathrm{H}$ shows the final level of potentiation reached by each pathway in WT and mutant mice in the presence or in the absence of APV.
Thus, an LTP independent of NMDA receptors can be induced in the absence of $\alpha \mathrm{CaMKII}$ autophosphorylation. However, this LTP is not restricted to activated synapses.

\section{Increasing cAMP concentration induces an LTP which is independent of $\alpha \mathrm{CaMKII}$ autophosphorylation}

To test the role of $\alpha$ CaMKII autophosphorylation in chemical LTP, we induced it by applying forskolin and IBMX, two drugs that increase the concentration of cAMP, during $15 \mathrm{~min}$ on slices dissected from WT or T286A mice (Chavez-Noriega and Stevens 1992; Capron et al. 2006). For these experiments, the CA3 region of each slice was cut to prevent drug-induced epilepsy.

Immediately after the addition of the drugs, the synaptic strength increased to $224 \pm 28 \%$ in mutant mice, a value which is similar to that obtained in WT mice (202 $\pm 15 \%$, Student's $t$-test, $P=0.467$, Fig. 3A). The level of potentiation then decreased but was maintained to $129 \pm 7 \%$ in mutant mice $4 \mathrm{~h}$ after the induction. Likewise, the level of potentiation was identical to that obtained in WT mice $(144 \pm 10 \%$ at the end of the experiment, Student's $t$-test $P=0.278$ ). The increase of synaptic strength induced by forskolin and IBMX was not due to an increase in axon excitability as the amplitude of the fiber volley was not modified over time (see recording traces inserted in Fig. 3A,C). 
A

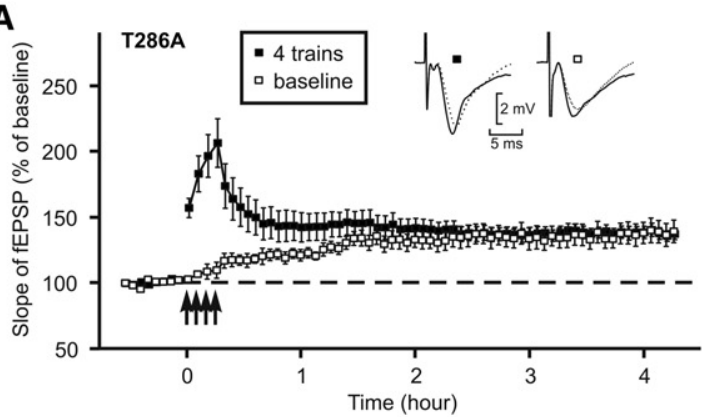

C

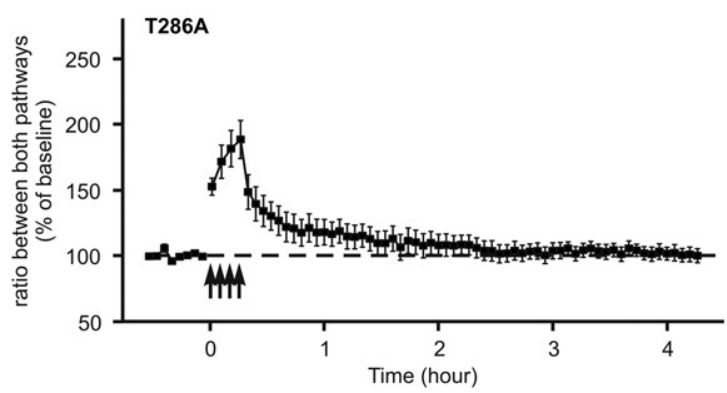

E

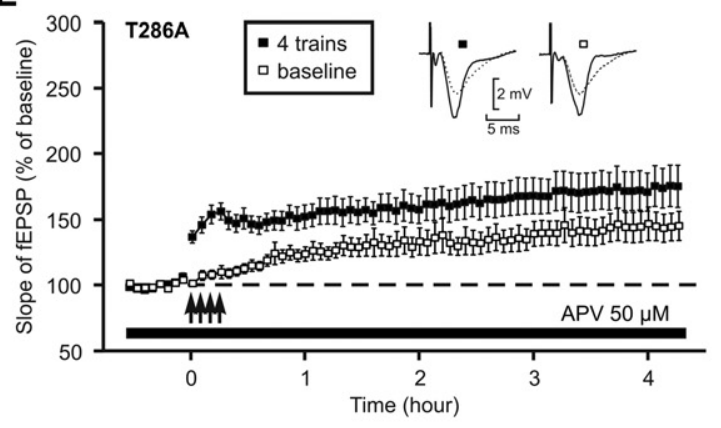

G

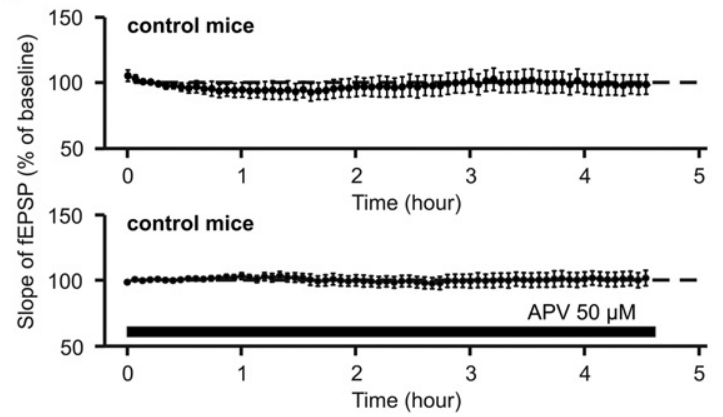

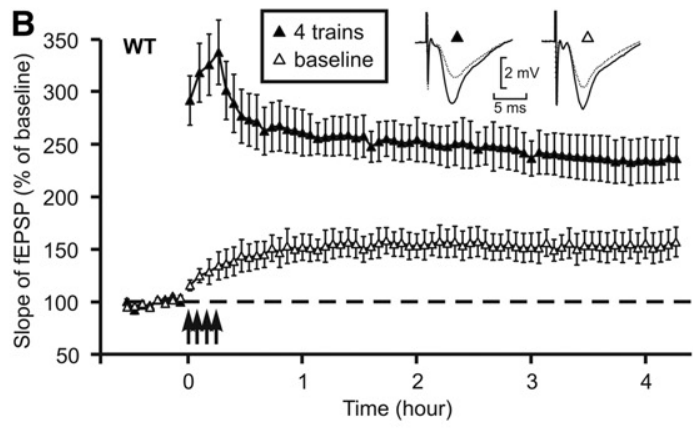

D
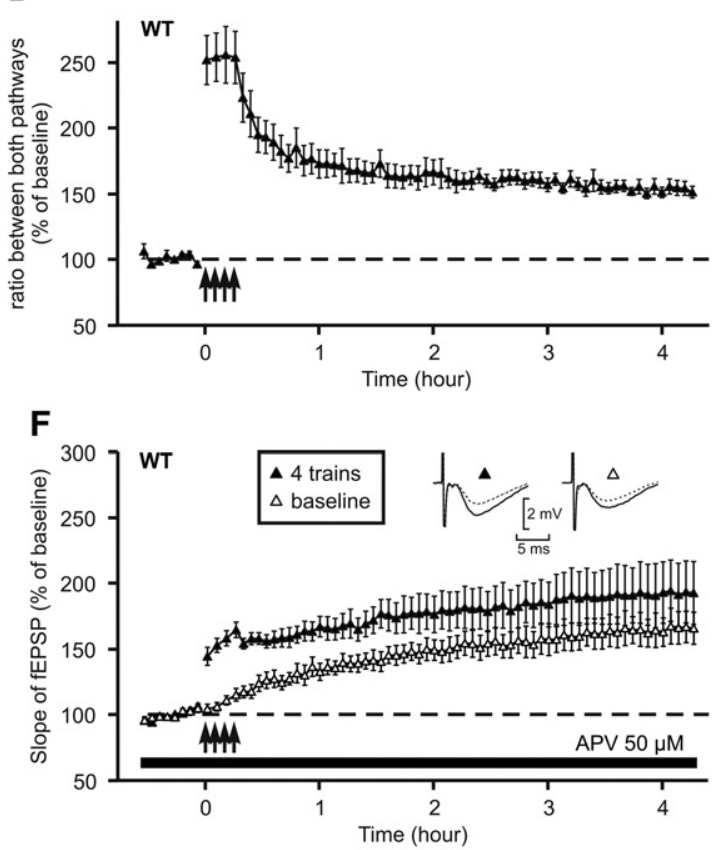

H

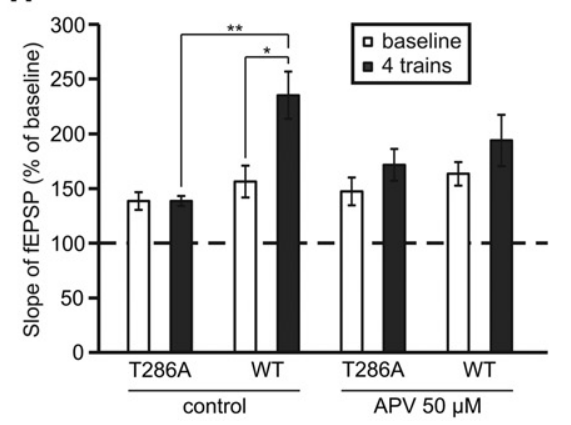

Figure 2. LTP induced in T286A mutant mice after a recovery period in submersion is not specific to stimulated synapses and is independent of NMDA receptors. $(A, B)$ After a recovery period in submersion, LTP was triggered using four trains of high-frequency stimulation (arrows). The graphs present the evolution of the fEPSP slope in the stimulated (black symbols) and control (empty symbols) pathways. Insets show fEPSP waveforms, recorded just before LTP induction (dotted trace) or $4 \mathrm{~h}$ afterward (full trace). $(A)$ On slices from T286A mice $(n=7)$. $(B)$ On slices from wild-type mice $(n=5)$. (C,D) Calculation of the ratio between the two stimulating pathways, on slices from T286A ( $C$, based on $A)$, or wild-type $(D$, based on $B)$ mice, showing that the potentiation observed in $A$ was not synapse-specific. $(E, F)$ After a recovery period in submersion, the slices were incubated with APV ( $50 \mu M)$, applied $30 \mathrm{~min}$ before LTP induction until the end of the experiment. The graphs present the evolution of the slope of the fEPSP measured in the stimulated (black symbols) and unstimulated (empty symbols) pathways. Insets show fEPSP waveforms, recorded just before LTP induction (dotted trace) or 4 $\mathrm{h}$ afterward (full trace). (E) In slices from T286A mice $(n=6)$. ( $F$ ) In slices from wild-type mice. (G) Time-course of the slope of the fEPSP in the absence of high-frequency stimulation, on slices from control mice with $(n=10)$ and without $(n=6)$ APV. $(H)$ Bar graph comparing the level of potentiation of the stimulated (black columns) and unstimulated (empty columns) pathways reached $4 \mathrm{~h}$ after LTP induction after a recovery period in submersion in the presence or absence of APV. $\left({ }^{*}\right) P<0.05$, Student's $t$-test; $\left(^{* *}\right) P<0.05$, Mann-Whitney rank-sum test. 
A

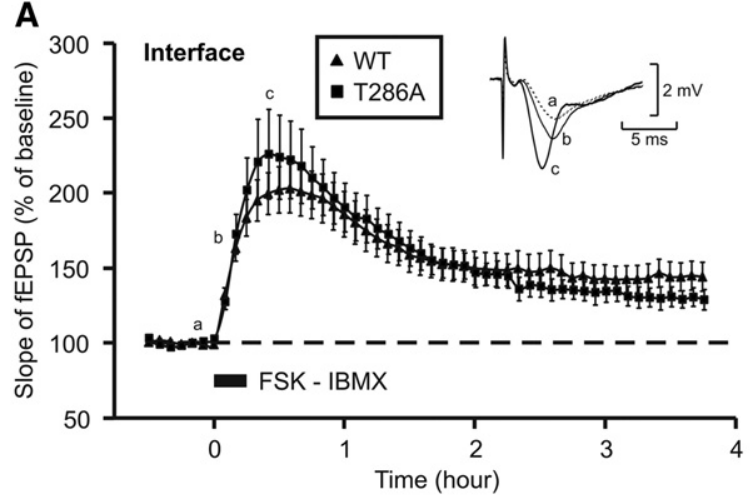

C

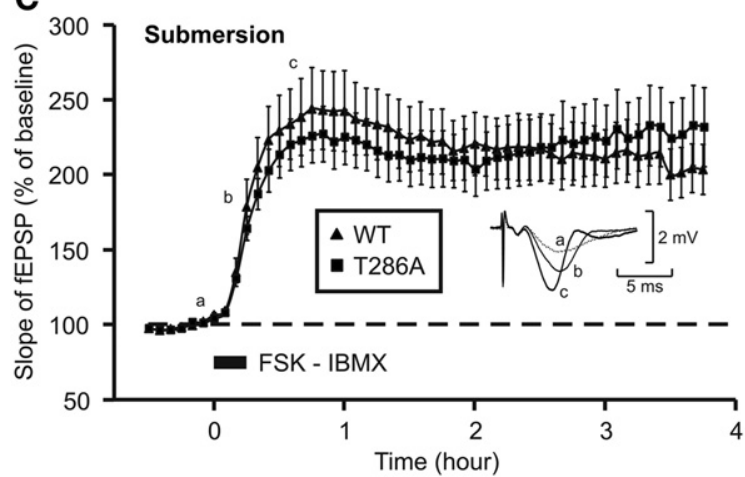

E

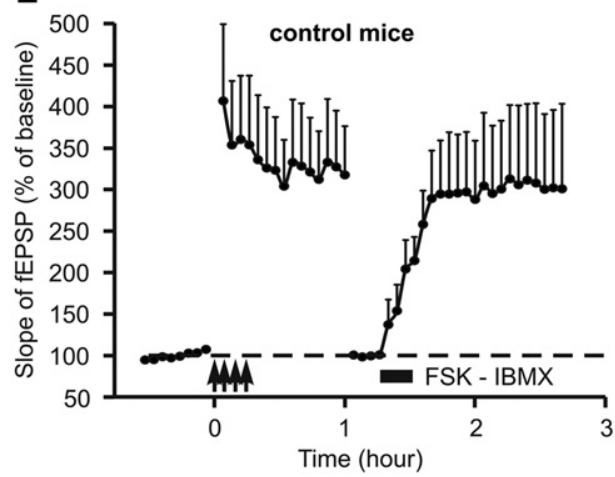

$\mathbf{F}$
B

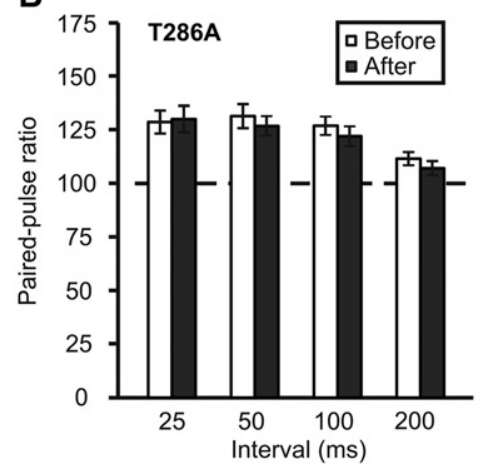

D
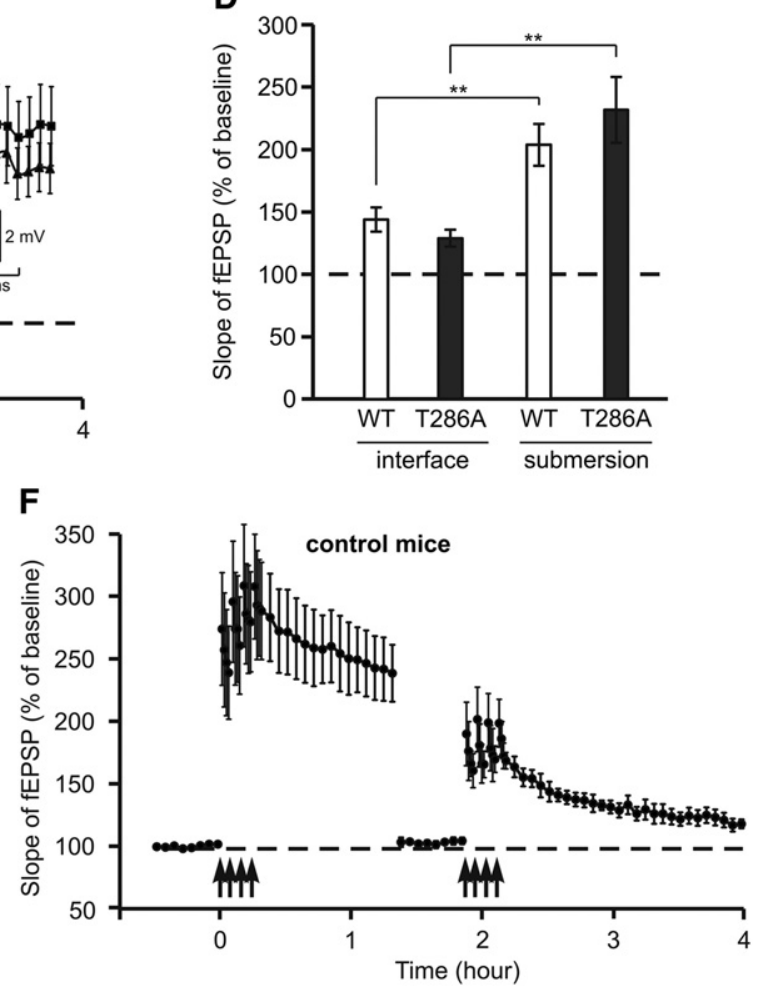

Figure 3. LTP induced by an increase in CAMP concentration is independent of $\alpha$ CaMKII autophosphorylation. ( $A$ ) After a recovery period in interface, the graph presents the evolution of the slope of the fEPSP, while LTP was induced chemically by a 15 -min perfusion of forskolin (50 $\mu$ M) and IBMX $(30 \mu \mathrm{M})$, on slices from wild-type mice (triangles, $n=10$ ) and T286A mice (squares, $n=6$ ). Insets show fEPSP waveforms recorded at three time points during LTP induction. (B) After a recovery period in interface, paired-pulse facilitation was recorded on slices from mutant mice $(n=8)$ before (empty columns) and $4 \mathrm{~h}$ after the chemical induction of LTP (black columns). (C) After a recovery in submersion, the graph presents the evolution of the slope of the fEPSP, while LTP was induced by forskolin and IBMX on slices from wild-type mice (triangles, $n=7$ ) and T286A mice (squares, $n=$ 6). Insets show fEPSP waveforms recorded at three time points during LTP induction. (D) Bar graph comparing the level of potentiation reached $4 \mathrm{~h}$ after LTP induction on slices from wild-type (empty columns) or T286A (black columns) mice, for both recovery conditions. (**) $P<0.01$. ( $E$ ) Chemically induced LTP is not occluded by electrically induced LTP. Time-course of the slope of fEPSP on slices from control C57BI6 mice $(n=4)$. LTP was triggered by four trains of high-frequency stimulation (arrows). One hour after induction, stimulation intensity was reduced to evoke fEPSP in the same range than the baseline level. Then, chemical LTP was induced by a 15-min incubation with forskolin $(50 \mu \mathrm{M})$ and IBMX (30 $\mu$ M). (F) LTP induced by four trains is saturated. Time-course of the slope of fEPSP on slices from control C57BI6 mice $(n=4)$. LTP was triggered by four trains of highfrequency stimulation (arrows). One hour after induction, stimulation intensity was reduced to evoke fEPSP in the same range than the baseline level. Then, electrical LTP was again induced by four trains (arrows).

Consequently, we can say that chemical LTP, which is not limited to one set of synapses as the drugs have a neuron-wide effect, is not dependent on $\alpha$ CaMKII autophosphorylation contrary to electrically induced LTP. These two forms of LTP are not mutually exclusive as it was possible to induce chemical LTP after electrical LTP (Fig. 3E) whereas a second HFS was not able to induce a stable increase of synaptic strength (Fig. 3F) demonstrating the saturation of the first induced potentiation.
As the effect of the drugs can be pre- or postsynaptic, we compared the efficacy of paired-pulse facilitation before and $4 \mathrm{~h}$ after the induction of LTP. In the case of a presynaptic increase in synaptic strength, we should have observed a reduction in pairedpulse facilitation. Yet, for the four intervals tested $(25,50,100$, and $200 \mathrm{msec}$ ), the facilitation was strictly identical (Fig. 3B).

Then we tested whether the incubation of slices in submersion during the recovery period could further increase the level 
of potentiation induced by forskolin and IBMX. We can see in Figure 3C that the induction of LTP was not modified by the incubation of the slices in submersion. However, this potentiation was maintained at the same level during $4 \mathrm{~h}$ in mutant and WT mice $(232 \pm 26 \%$ in mutant and $204 \pm 17 \%$ in WT, Student's $t$-test $P=$ 0.375 ). This could be explained by the addition of a slow-onset potentiation to the immediate potentiation induced by the drugs.

The final level of potentiation reached in WT and mutant mice $4 \mathrm{~h}$ after the application of forskolin and IBMX is presented in Figure 3D for the interface and the submersion conditions.

\section{Specific LTP can be induced in T286A mice in the presence of rapamycin}

In T286A mice, immediate learning was impaired, but when the task was repeated in a massed training protocol of fear conditioning, learning occurred (Irvine et al. 2005). Radwanska et al. (2011) showed that this learning could be impaired by rapamycin.

We thus studied the effect of rapamycin on the LTP induced by four trains in mutant mice after a recovery period in submersion. Surprisingly, instead of inhibiting LTP, the incubation of slices with rapamycin increased the potentiation level of the stimulated pathway (Fig. 4A).

Four hours after HFS, the potentiation reached a level of $157 \pm 10 \%$ in slices prepared from mutant mice and incubated with rapamycin $(1 \mu \mathrm{M})$ from $2 \mathrm{~h}$ before until $4 \mathrm{~h}$ after induction. At the same time, the control pathway presented a slow increase in synaptic strength which did not reach the level of the pathway stimulated by HFS $(124 \pm 9 \%$, Student's $t$-test $P<0.05)$. Even when we did not take the effect which was not synapse-specific into account, a stable synapse-specific LTP was observed in T286A mice. The level of potentiation was maintained at $128 \pm 9 \% 4 \mathrm{~h}$ after the induction (Fig. $4 \mathrm{C})$. The final level of potentiation reached by the stimulated and the nonstimulated pathways in the presence or absence of rapamycin is shown in Figure 4B.

Long-term incubation of slices with rapamycin increases NMDAdependent synaptic activity

As a part of the increase in synaptic strength observed in the presence of rapamycin in mutant mice was restricted to activated synapses, we hypothesized that it could be due to an increased efficacy of NMDA receptors.

We thus measured the slope of NMDA fEPSP before and after rapamycin incubation in the presence of $\mathrm{Mg}$-free ACSF added with CNQX $(50 \mu \mathrm{M})$ in T286A mice (Fig. 5A) and in WT mice (Fig. 5C).

We observed a significant increase in NMDA fEPSP slope after a 2-h rapamycin incubation although AMPA synaptic responses remained stable in mutant mice (Fig. 5B) and WT mice (Fig. 5D). In mutant mice, the maximal slope of NMDA fEPSP increased from $0.7 \pm 0.2$ to $2.0 \pm 0.2 \mathrm{mV} / \mathrm{msec}$. Similarly, the maximal slope of NMDA fEPSP of WT mice increased from $0.5 \pm 0.1$ to $1.6 \pm 0.2 \mathrm{mV} / \mathrm{msec}$.

We checked that the increase in NMDA fEPSP response was not due to time, to the first CNQX incubation or the permutation of incubating solutions by omitting rapamycin in a sham experiment in WT mice (Fig. 5E,F). In this case the amplitudes of NMDA fEPSP and of AMPA fEPSP were left unchanged during the 3-h experiment.

More surprisingly, the incubation of slices with rapamycin revealed a polysynaptic NMDA response to Schaffer collaterals stimulation (Fig. 5G). This polysynaptic response dramatically increased the duration of the fEPSP, which in turn probably increased the amount of calcium influx into postsynaptic dendritic spines.

\section{Discussion}

T286A mutation impairs the specific increase of AMPA synaptic responses to electrical stimulation

The input/output curves of AMPA fEPSPs and NMDA fEPSPs were not different in mutant and WT mice. This result suggests that $\alpha$ CaMKII autophosphorylation is not required for the basal insertion of AMPA and NMDA receptors into the synaptic membrane. The slope of NMDA-dependent fEPSP measured in the presence of Mg-free ACSF added with CNQX $(50 \mu \mathrm{M})$ was identical in mutant and WT mice with a maximal value of $0.7 \pm 0.2$ and $0.5 \pm$ $0.1 \mathrm{mV} / \mathrm{msec}$, respectively, a result which is consistent with that obtained by Giese et al. in the original paper of 1998. This suggests that the calcium entry induced by high-frequency stimulation will be equivalent in both groups of mice. This entry is sufficient to
A
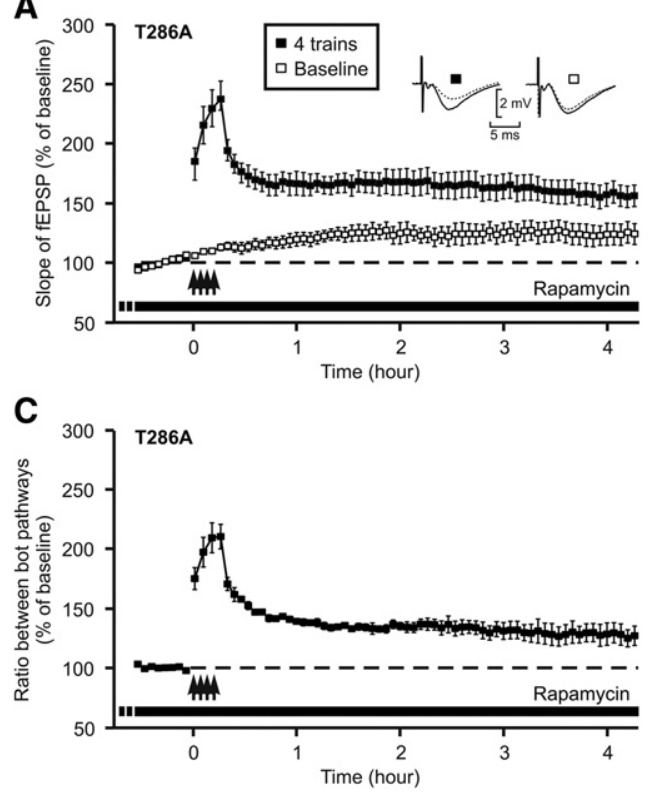

Figure 4. Specific LTP can be induced in T286A mice in the presence of rapamycin. (A) Time-course of the slope of the fEPSP in T286A mice in the presence of rapamycin. Rapamycin $(1 \mu \mathrm{M})$ was applied from the beginning of the recovery period in submersion till the end of the experiment. LTP was triggered by four trains of high-frequency stimulation (arrows) on slices from T286A mice $(n=4)$. Insets show fEPSP waveforms, recorded just before LTP induction (dotted trace) or $4 \mathrm{~h}$ afterward (full trace). (B) Bar graph comparing the level of potentiation of the stimulated (black columns) and unstimulated (empty columns) pathways reached $4 \mathrm{~h}$ after LTP induction under control condition or in the presence of rapamycin. $\left(^{*}\right) P<0.05$. (C) Calculation of the ratio between the two stimulating pathways showed that a part of potentiation illustrated in $A$ was specific of the stimulated pathway. (D) Bar graph comparing the level of specific potentiation (after calculation of the ratio) reached $4 \mathrm{~h}$ after LTP induction under control condition or in the presence of rapamycin. $\left(^{*}\right) P<0.05$, Student's $t$-test. 


\section{NMDA responses}

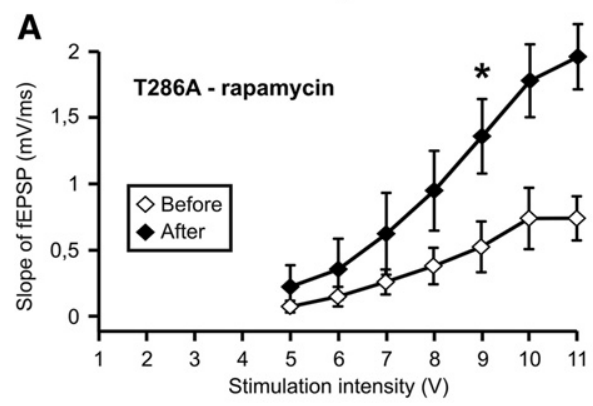

C

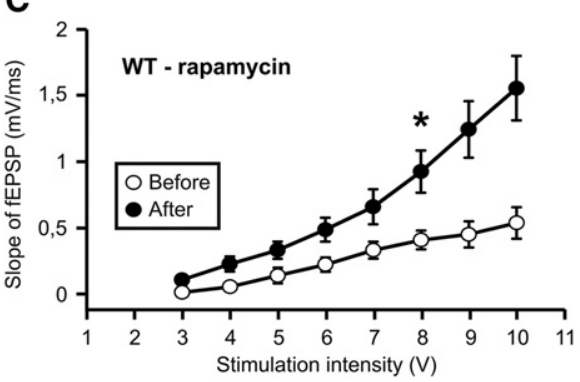

E

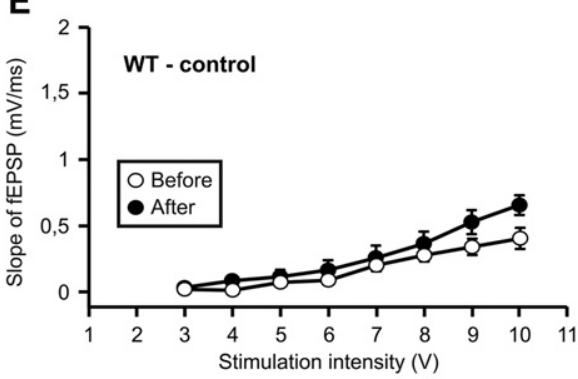

AMPA responses

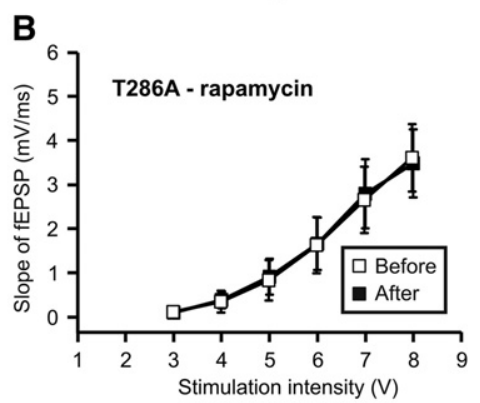

D

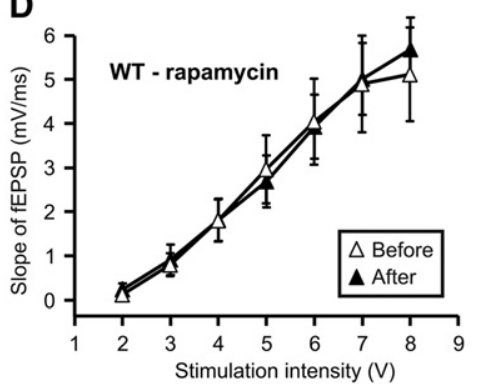

$\mathbf{F}$

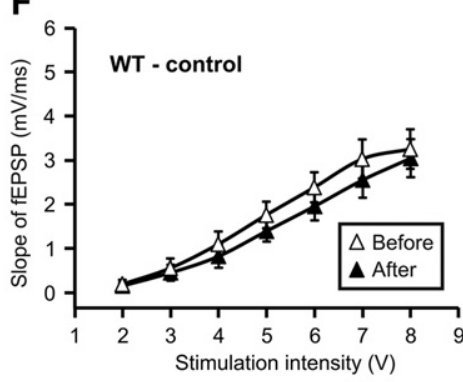

G

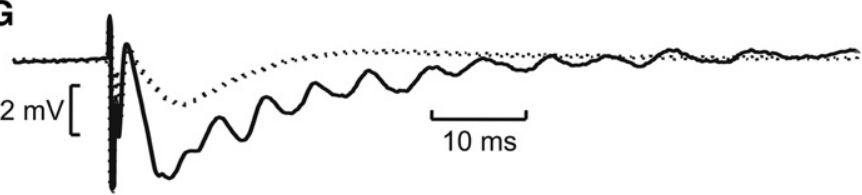

Figure 5. Long-term incubation of slices with rapamycin increases NMDA receptor-mediated synaptic transmission. $(A-D)$ Input/output relationships of NMDA receptor and AMPA receptor-mediated responses (respectively, left and right) were recorded before (empty circles) and after (black circles) a 2-h incubation with rapamycin $(1 \mu \mathrm{M})$, on slices from T286A mice $(A, B, n=4)$ and wild-type mice $(C, D, n=4)$. NMDAR-mediated responses were recorded in the presence of CNQX and in the absence of $\mathrm{Mg}^{2+}$. $(E, F)$ Input/output relationships of NMDA receptor and AMPA receptor-mediated responses were recorded at 2-h interval under control conditions on slices from wild-type mice $(n=4)$. $\left(^{*}\right)$ $P<0.05$, Student's $t$-test. (G) NMDA receptor-mediated fEPSP recorded before (dotted trace) and after (full trace) a 2-h perfusion with rapamycin $(1 \mu \mathrm{M})$, showing emergence of polysynaptic NMDA activity.

trigger an immediate increase in synaptic strength which could be due to the phosphorylation of preexisting AMPA receptors by PKA (Lee et al. 2000). Indeed, calcium entry could activate adenylate cyclase increasing the production of cAMP, which activates PKA (Wei et al. 2006). This early LTP could also be due to $\alpha$ CaMKII activation by calcium/calmodulin leading to phosphorylation of GluR1 subunit of AMPA receptors on S831 (Coultrap et al. 2012). However, this increase in fEPSP remained largely smaller than that observed in WT mice and is not maintained over time in mutant mice. The impairment of LTP induced by HFS in T286A mice was demonstrated previously for LTP induced by four trains at $50 \mathrm{~Hz}$ (Irvine et al.
2011) and two groups of four trains at 50 $\mathrm{Hz}$ (Radwanska et al. 2011). In this paper, we presented the data of LTP induced by four trains at $100 \mathrm{~Hz}$ but no other kind of electrical stimulation $(200 \mathrm{~Hz}$ (Cavus and Teyler 1996) or TBS (Larson et al. 1986)) was able to induce a sustained increase in synaptic strength (data not shown).

\section{Impact of recovery conditions on excitability and LTP}

Just after dissection, acute hippocampal slices must recover during a minimum of $1 \mathrm{~h}$ before starting any experiment. However, recovery conditions modify the properties of LTP induced by highfrequency stimulation (Capron et al. 2006). When the recovery period occurs in submersion, the potentiation reaches a higher level and is maintained at this high level throughout the experiment.

In this study, after a period of incubation in submersion, the slices prepared from mutant mice presented a higher level of potentiation just after the induction and a small increase in synaptic strength was observed during $4 \mathrm{~h}$. However, this increase was correlated to a slow-onset potentiation of the unstimulated pathway (which did not receive any HFS). This increase, which was not synapse-specific, was independent of NMDA receptors as it was still present and even increased in the presence of APV, an NMDA receptor antagonist. Giese et al. (1998) also found some NMDA receptor-independent LTP but did not test for input specificity. These results suggested that the postsynaptic neurons responded to the HFS by a general activation not restricted to dendritic spines. This general activation presented a slow onset and a progressive installation. This kind of potentiation could be associated with L-type VDCC activation as shown in the studies of Tayler et al. (Grover and Teyler 1990; Cavus and Teyler 1996). Grover and Yan (1999) showed that this VDCC-dependent LTP was facilitated by postsynaptic depolarization and action potential back-propagation.

We hypothesize that the incubation in submersion leads to an increased neuronal excitability and to the activation of L-type VDC channels by a relatively weak stimulus. As VDCC are located in the dendrites, close to the neck of dendritic spines, their activation cannot be synapse-specific. The entry of calcium through NMDA receptors is isolated in dendritic spines while the increase in calcium concentration mediated by VDCC or reticulum endoplasmic channels is more general and concerns more synapses (Malenka 1991).

During the resting period in submersion we increased the flow rate of perfusion to $2 \mathrm{~mL} / \mathrm{min}$. As the volume of the chamber is $1 \mathrm{~mL}$, it will be renewed every $30 \mathrm{sec}$. Moreover, during this period, slices are covered only by a thin layer of liquid because they 
are allowed to float freely at the surface of the liquid (Capron et al. 2006). Nevertheless, this procedure could provide less oxygenation to the slices than the interface condition. A mild hypoxia of the slices during the recovery period could be at the origin of the increase in excitability. The increased neuronal excitability observed in submersion could also be due to signaling through BDNF released by neurons (Kuczewski et al. 2008) or TNF- $\alpha$ release by astrocytes. BDNF can have NMDA-dependent and NMDA-independent actions (Li and Keifer 2009) while LTP induced by TNF- $\alpha$ can appear after a trauma in the spinal cord (Liu et al. 2007).

On the other hand, Ito and Schuman (2009) showed that the presence of A-type potassium channels along the dendrites could influence the regulation of AMPA receptors insertion into synaptic membranes. A redistribution of this kind of channels could therefore induce homeostatic regulation of synaptic strength.

\section{A possible role for $\beta$ subunits of CaMKII}

The generation of null mutant mice that do not express $\alpha$ CaMKII protein allowed to demonstrate that $\alpha$ CaMKII controlled presynaptic plasticity (Hinds et al. 2003) in a way independent of its kinase activity (Hojjati et al. 2007). Postsynaptic LTP was also impaired in these mice (Silva et al. 1992b) but not totally absent (Hinds et al. 1998) suggesting a compensatory role of $\beta$ CaMKII which can be autophosphorylated at T287 (Brocke et al. 1999). However, in T286A mice, $\alpha$ CaMKII is present and cannot be replaced by $\beta$ CaMKII. The holoenzyme consisting of heteromeric complexes of the $\alpha$ CaMKII and $\beta$ CaMKII isoforms is targeted to synapses in a way dependent of the presence of $\beta$ CaMKII (Borgesius et al. 2011) and of the state of phosphorylation of the inhibitory site T305 or 306 of $\alpha$ CaMKII (Elgersma et al. 2002). In vivo, the calmodulin dependence for autophosphorylation of the $\beta$ subunits is shifted toward that of $\alpha$ homomers, suggesting that T287 in $\beta$ subunits is phosphorylated by $\alpha$ subunits present in the same holoenzyme (Brocke et al. 1999).

\section{Chemical LTP}

LTP can be induced chemically by activating enzymes downstream from calcium entry. In this case, LTP is not restricted to electrically activated synapses. In this study, we used forskolin and IBMX to induce long-lasting LTP in hippocampal slices after a resting period in interface or in submersion.

The mechanisms underlying this potentiation are still unclear and there is no definite evidence that cAMP can strengthen synaptic transmission by a CaMKII-independent mechanism. Blitzer et al. (1998) suggested that the activation of PKA by cAMP could inhibit the activity of protein phosphatase PP1 through the activation of inhibitor 1. As PP1 dephosphorylates CaMKII, it was suggested that PKA can extend the duration of the CaMKII autophosphorylation state, leading to CaMKII-dependent LTP. Yet, during chemical-LTP (c-LTP), there is an NMDAdependent accumulation of CaMKII in the dendritic spines (Otmakhov et al. 2004b). Makhinson et al. (1999) have showed that NMDA antagonists or CaMKII inhibitors can block the potentiation and the structural changes that are produced by activation of the cAMP pathway. Otmakhov et al. (2004a) showed that cLTP was dependent on NMDA receptors, a finding that we have partially confirmed previously (Capron et al. 2006). However, in this study, the increase in synaptic strength induced by forskolin and IBMX was independent of the mechanisms induced by electrical stimulation. Indeed, chemical LTP can be induced in slices which have undergone an electrical LTP which was shown to be saturated. Yet, our results showed that the chemical LTP was independent of $\alpha$ CaMKII autophosphorylation as it reached exactly the same level in WT and mutant mice. The potentiation was maintained at $>140 \%$ during $4 \mathrm{~h}$. In comparison, Otmakhov et al. (2004a) showed a decreasing LTP induced by forskolin and rolipram in normal conditions and a sustained LTP in the presence of picrotoxin. This LTP was dependent on NMDA receptors, but the combination of picrotoxin and forskolin/rolipram induced an epileptic activity. In our preparation, we did not use picrotoxin and the epileptic activity was prevented by cutting the CA3 region.

After a recovery period in submersion, the LTP induced by forskolin and IBMX was maintained at a higher level than after a recovery period in interface. This was observed in WT and in mutant mice. This suggests that two different cascades could be induced by the drugs and add their effects. Here again, the cut of CA3 region prevent the apparition of epileptic activity in the slices.

The long duration of drug application can explain the independence of synaptic plasticity from $\alpha$ CaMKII autophosphorylation. As the stimulus is long and not restricted to dendritic spines, it can activate CaMKII and induce its translocation into synapses. The short activation of adenylate cyclase by calcium/ calmodulin during HFS stimulation (Uhlén and Wikberg 1988) might not be sufficient to allow the translocation of CaMKII.

\section{Rapamycin effect}

Rapamycin has been reported to inhibit LTP through its action on mTOR-dependent translation (Gong et al. 2006). However, in our case, as LTP had been shown to be resistant to the presence of protein synthesis inhibitors (Villers et al. 2012), this effect was not present. Conversely, a specific form of potentiation was observed in slices prepared from mutant mice and incubated with rapamycin. This effect was assumed to be related to NMDA receptor activation and $\alpha$ CaMKII translocation. A large increase in NMDA fEPSP was observed at the very moment of LTP induction, which probably caused a much longer-lasting calcium entry into dendritic spines. This entry of calcium by NMDA receptors remained restricted to dendritic spines and thus led to synapse-specific LTP. Longer calcium waves might therefore lead to a longer presence of the calcium/calmodulin complex and to a longer activation of CaMKII even in the absence of autophosphorylation.

The mechanisms underlying NMDA fEPSP increase after $2 \mathrm{~h}$ of incubation with rapamycin are unknown and cannot be generalized as this increase cannot be reproduced in another strain of mice (C57B16, data not shown). Polysynaptic responses mediated by AMPA and NMDA receptors have already been shown in the CA1 region of rat hippocampus after blocking GABAa receptors (Crépel et al. 1997). On the other hand, rapamycin induces Kv1.1 synthesis in dendrites (Raab-Graham et al. 2006) leading to modifications in neuronal excitability.

\section{Conclusion}

Taken together, our findings suggest that $\alpha$ CaMKII autophosphorylation is not necessary to induce several forms of potentiation in the CA1 region of hippocampus. However, the increase in synaptic strength was not restricted to stimulated synapses. Because synapse specificity is a key element in the learning capacity of the neuronal networks, this cell-wide LTP cannot be related to specific learning processes. $\alpha$ CaMKII autophosphorylation seems therefore necessary to guarantee the synapse specificity of plasticity and learning and memory.

However, if the duration and the amplitude of NMDA receptor-mediated response were artificially increased then synapse-specific LTP could be induced in the absence of autophosphorylation. We propose that $\alpha$ CaMKII autophosphorylation, which is necessary for learning induced by a single trial, is also required for synaptic plasticity induced by a short and precise stimulus but maybe not for a longer and stronger stimulation. 


\section{Materials and Methods}

\section{Slice electrophysiology}

The experiments were performed on transverse hippocampal slices from adult $\alpha$ CaMKII-T286A mice and wild-type littermates generated as described (Giese et al. 1998) and for some experiments from $\mathrm{C} 57 \mathrm{Bl} / 6$ mice. The hippocampus was dissected and cut into $400-\mu \mathrm{m}$-thick slices with a tissue chopper. Hippocampal slices were perfused with artificial cerebrospinal fluid (ACSF) with the following composition: $124 \mathrm{mM} \mathrm{NaCl}, 5 \mathrm{mM} \mathrm{KCl}, 26 \mathrm{mM}$ $\mathrm{NaHCO}_{3}, 1.24 \mathrm{mM} \mathrm{NaH} \mathrm{PO}_{4}, 2.5 \mathrm{mM} \mathrm{CaCl}_{2}, 1.3 \mathrm{mM} \mathrm{MgSO}_{4}$ $10 \mathrm{mM}$ D-glucose, bubbled with a mixture of $95 \% \mathrm{O}_{2}$ and $5 \%$ $\mathrm{CO}_{2}$. Mice were anaesthetized and decapitated. The slices were transferred into the recording chamber and kept in an interface or a submersion chamber at $28^{\circ} \mathrm{C}$ for $1.5 \mathrm{~h}$. The perfusion rate of ACSF was $1 \mathrm{~mL} / \mathrm{min}$ for interface and $2 \mathrm{~mL} / \mathrm{min}$ for submersion chamber. Recordings were performed in interface chamber. Bipolar twisted nickel-chrome electrodes (50 $\mu \mathrm{m}$ each) were used to stimulate two distinct bundles of Schaffer collaterals. Extracellular field excitatory postsynaptic potentials (fEPSP) were recorded in the stratum radiatum of the CA1 region with low resistance (2$5 \mathrm{M} \Omega$ ) glass microelectrodes filled with ACSF. Test stimuli were biphasic constant-voltage pulses ( $0.08 \mathrm{msec}$ for each pulse) delivered every minute with an intensity adjusted to evoke $\sim 40 \% \max$ imal response. The slope of the fEPSP was measured on the average of four consecutive responses. Independence of both pathways was ascertained by applying two pulses with a 50-msec interval to the two pathways and verifying the absence of paired-pulse facilitation. Synaptic fatigue was assessed by measuring the amplitude of the fEPSP induced by the first 10 stimulations of the first train. LTP was induced by applying four trains $(100-\mathrm{Hz}, 1-\mathrm{sec}$, 5 -min interval) or a mixture of forskolin $(50 \mu \mathrm{M}$, Alomone) and IBMX (30 $\mu$ M, Sigma). In both protocols, the potentiated response was recorded for $4 \mathrm{~h}$. For each slice, the fEPSP slopes were normalized with respect to the mean slope of the fEPSPs recorded during the 30-min period preceding induction of LTP. When slices were allowed to recover in a submersion chamber, the initial response increased during the first $20 \mathrm{~min}$ and then remained stable for the rest of the experiment. In this case the baseline was started after stabilization. To determine whether or not the normalized fEPSP of a group of slices submitted to the same experimental conditions was significantly potentiated $(P<0.05)$, the percentages of baseline measured after induction of LTP were compared using a two-way ANOVA and several Student's $t$-tests at different times after LTP induction. In some experiments, rapamycin $(1 \mu \mathrm{M}$, Tocris) or APV (50 $\mu \mathrm{M}$, Tocris) was added to ACSF. NMDA fEPSP were measured in the presence of Mg-free ACSF added with CNQX (disodium salt, $20 \mu \mathrm{M}$, Tocris). Rapamycin, forskolin, and IBMX were diluted in DMSO (0.1\% final concentration) while $\mathrm{APV}$ and $\mathrm{CNQX}$ were diluted in water.

\section{Acknowledgments}

This work was generously supported by the Belgian Queen Elisabeth Medical Foundation and by the Belgian Fund for Scientific Research (FRS-FNRS). We thank Deborah Waimberg for correcting the English.

Authors' contributions: K.P.G. bred and genotyped the $\alpha$ CaMKII-T286A mutants. A.V. performed the electrophysiological recordings. L.R. and K.P.G. designed the experiments and wrote the paper.

\section{References}

Barria A, Malinow R. 2005. NMDA receptor subunit composition controls synaptic plasticity by regulating binding to CaMKII. Neuron 48: 289-301.

Bayer KU, De Koninck P, Leonard AS, Hell JW, Schulman H. 2001. Interaction with the NMDA receptor locks CaMKII in an active conformation. Nature 411: 801-805.

Blitzer RD, Connor JH, Brown GP, Wong T, Shenolikar S, Iyengar R, Landau EM. 1998. Gating of CaMKII by cAMP-regulated protein phosphatase activity during LTP. Science 280: 1940-1942.
Borgesius NZ, van Woerden GM, Buitendijk GHS, Keijzer N, Jaarsma D, Hoogenraad CC, Elgersma Y. 2011. $\beta$ CaMKII plays a nonenzymatic role in hippocampal synaptic plasticity and learning by targeting $\alpha$ CaMKII to synapses. I Neurosci 31: 10141-10148.

Brocke L, Chiang LW, Wagner PD, Schulman H. 1999. Functional implications of the subunit composition of neuronal CaM kinase II. I Biol Chem 274: 22713-22722.

Broutman G, Baudry M. 2001. Involvement of the secretory pathway for AMPA receptors in NMDA-induced potentiation in hippocampus. J Neurosci 21: 27-34.

Buard I, Coultrap SJ, Freund RK, Lee YS, Dell'Acqua ML, Silva AJ, Bayer KU. 2010. CaMKII "autonomy" is required for initiating but not for maintaining neuronal long-term information storage. J Neurosci 30: $8214-8220$.

Capron B, Sindic C, Godaux E, Ris L. 2006. The characteristics of LTP induced in hippocampal slices are dependent on slice-recovery conditions. Learn Mem 13: 271-277.

Cavus I, Teyler T. 1996. Two forms of long-term potentiation in area CA1 activate different signal transduction cascades. J Neurophysiol 76: 3038-3047.

Chao LH, Stratton MM, Lee IH, Rosenberg OS, Levitz J, Mandell DJ, Kortemme T, Groves JT, Schulman H, Kuriyan J. 2011. A mechanism for tunable autoinhibition in the structure of a human $\mathrm{Ca}^{2+} /$ calmodulindependent kinase II holoenzyme. Cell 146: 732-745.

Chavez-Noriega LE, Stevens CF. 1992. Modulation of synaptic efficacy in field CA1 of the rat hippocampus by forskolin. Brain Res 574: 85-92.

Coultrap SJ, Bayer KU. 2012. CaMKII regulation in information processing and storage. Trends Neurosci 35: 607-618.

Coultrap SJ, Barcomb K, Bayer KU. 2012. A significant but rather mild contribution of T286 autophosphorylation to $\mathrm{Ca}(2+) / \mathrm{CaM}$-stimulated CaMKII activity. PLoS One 7: e37176.

Coultrap SJ, Freund RK, O'Leary H, Sanderson JL, Roche KW, Dell'Acqua ML, Bayer KU. 2014. Autonomous CaMKII mediates both LTP and LTD using a mechanism for differential substrate site selection. Cell Rep 6: $431-437$

Crépel V, Khazipov R, Ben-Ari Y. 1997. Blocking GABA(A) inhibition reveals AMPA- and NMDA-receptor-mediated polysynaptic responses in the CA1 region of the rat hippocampus. I Neurophysiol 77: 2071-2082.

De Koninck P, Schulman H. 1998. Sensitivity of CaM kinase II to the frequency of $\mathrm{Ca}^{2+}$ oscillations. Science 279: 227-230.

Dobrunz LE, Stevens CF. 1997. Heterogeneity of release probability, facilitation, and depletion at central synapses. Neuron 18: 995-1008.

Elgersma Y, Fedorov NB, Ikonen S, Choi ES, Elgersma M, Carvalho OM, Giese KP, Silva AJ. 2002. Inhibitory autophosphorylation of CaMKII controls PSD association, plasticity, and learning. Neuron 36: 493-505.

Erondu NE, Kennedy MB. 1985. Regional distribution of type II $\mathrm{Ca}^{2+} /$ calmodulin-dependent protein kinase in rat brain. J Neurosci 5: 3270-3277.

Esteban JA, Shi SH, Wilson C, Nuriya M, Huganir RL, Malinow R. 2003. PKA phosphorylation of AMPA receptor subunits controls synaptic trafficking underlying plasticity. Nat Neurosci 6: 136-143.

Fukunaga K, Stoppini L, Miyamoto E, Muller D. 1993. Long-term potentiation is associated with an increased activity of $\mathrm{Ca}^{2+} /$ calmodulin-dependent protein kinase II. J Biol Chem 268: 7863-7867.

Giese KP, Fedorov NB, Filipkowski RK, Silva AJ. 1998. Autophosphorylation at Thr286 of the $\alpha$ calcium-calmodulin kinase II in LTP and learning. Science 279: 870-873.

Glazewski S, Chen CM, Silva A, Fox K. 1996. Requirement for $\alpha$-CaMKII in experience-dependent plasticity of the barrel cortex. Science 272: $421-423$.

Glazewski S, Giese KP, Silva A, Fox K. 2000. The role of $\alpha$-CaMKII autophosphorylation in neocortical experience-dependent plasticity. Nat Neurosci 3: 911-918.

Gong R, Park CS, Abbassi NR, Tang SJ. 2006. Roles of glutamate receptors and the mammalian target of rapamycin (mTOR) signaling pathway in activity-dependent dendritic protein synthesis in hippocampal neurons. J Biol Chem 281: 18802-18815.

Greer PL, Greenberg ME. 2008. From synapse to nucleus: calcium-dependent gene transcription in the control of synapse development and function. Neuron 59: 846-860.

Griffith LC, Verselis LM, Aitken KM, Kyriacou CP, Danho W, Greenspan RJ 1993. Inhibition of calcium/calmodulin-dependent protein kinase in Drosophila disrupts behavioral plasticity. Neuron 10: 501-509.

Grover LM, Teyler TJ. 1990. Two components of long-term potentiation induced by different patterns of afferent activation. Nature 347: $477-479$.

Grover LM, Yan C. 1999. Blockade of GABAA receptors facilitates induction of NMDA receptor-independent long-term potentiation. J Neurophysiol 81: $2814-2822$.

Halt AR, Dallapiazza RF, Zhou Y, Stein IS, Qian H, Juntti S, Wojcik S, Brose N, Silva AJ, Hell JW. 2012. CaMKII binding to GluN2B is critical during memory consolidation. EMBO J 31: 1203-1216. 
Hanson PI, Meyer T, Stryer L, Schulman H. 1994. Dual role of calmodulin in autophosphorylation of multifunctional CaM kinase may underlie decoding of calcium signals. Neuron 12: 943-956.

Hayashi Y, Shi SH, Esteban JA, Piccini A, Poncer JC, Malinow R. 2000. Driving AMPA receptors into synapses by LTP and CaMKII: requirement for GluR1 and PDZ domain interaction. Science 287: 2262-2267.

Hinds HL, Tonegawa S, Malinow R. 1998. CA1 long-term potentiation is diminished but present in hippocampal slices from $\alpha$-CaMKII mutant mice. Learn Mem 5: 344-354.

Hinds HL, Goussakov I, Nakazawa K, Tonegawa S, Bolshakov VY. 2003. Essential function of $\alpha$-calcium/calmodulin-dependent protein kinase II in neurotransmitter release at a glutamatergic central synapse. Proc Natl Acad Sci 100: 4275-4280.

Hoffman L, Stein RA, Colbran RJ, Mchaourab HS. 2011. Conformational changes underlying calcium/calmodulin-dependent protein kinase II activation. EMBO J 30: 1251-1262.

Hojjati MR, van Woerden GM, Tyler WJ, Giese KP, Silva AJ, Pozzo-Miller L, Elgersma Y. 2007. Kinase activity is not required for $\alpha$ CaMKIIdependent presynaptic plasticity at CA3-CA1 synapses. Nat Neurosci 10: $1125-1127$.

Hudmon A, Schulman H. 2002. Neuronal $\mathrm{CA}^{2+}$ /calmodulin-dependent protein kinase II: the role of structure and autoregulation in cellular function. Annu Rev Biochem 71: 473-510.

Irvine EE, Vernon J, Giese KP. 2005. $\alpha$ CaMKII autophosphorylation contributes to rapid learning but is not necessary for memory. Nat Neurosci 8: 411-412.

Irvine EE, Danhiez A, Radwanska K, Nassim C, Lucchesi W, Godaux E, Ris L, Giese KP. 2011. Properties of contextual memory formed in the absence of $\alpha$ CaMKII autophosphorylation. Mol Brain 4: 8 .

Ito HT, Schuman EM. 2009. Distance-dependent homeostatic synaptic scaling mediated by A-type potassium channels. Front Cell Neurosci 3: 15.

Koh YH, Popova E, Thomas U, Griffith LC, Budnik V. 1999. Regulation of DLG localization at synapses by CaMKII-dependent phosphorylation. Cell 98: 353-363.

Kuczewski N, Porcher C, Lessmann V, Medina I, Gaiarsa JL. 2008. Back-propagating action potential: a key contributor in activitydependent dendritic release of BDNF. Commun Integr Biol 1: 153-155.

Larson J, Wong D, Lynch G. 1986. Patterned stimulation at the theta frequency is optimal for the induction of hippocampal long-term potentiation. Brain Res 368: 347-350.

Lee HK, Barbarosie M, Kameyama K, Bear MF, Huganir RL. 2000. Regulation of distinct AMPA receptor phosphorylation sites during bidirectional synaptic plasticity. Nature 405: 955-959.

Lee SJR, Escobedo-Lozoya Y, Szatmari EM, Yasuda R. 2009. Activation of CaMKII in single dendritic spines during long-term potentiation. Nature 458: 299-304

Lemieux M, Labrecque S, Tardif C, Labrie-Dion E, Lebel E, De Koninck P. 2012. Translocation of CaMKII to dendritic microtubules supports the plasticity of local synapses. J Cell Biol 198: 1055-1073.

Lengyel I, Voss K, Cammarota M, Bradshaw K, Brent V, Murphy KPSJ, Giese KP, Rostas JAP, Bliss TVP. 2004. Autonomous activity of CaMKII is only transiently increased following the induction of long-term potentiation in the rat hippocampus. Eur J Neurosci 20: 3063-3072.

Leonard AS, Bayer KU, Merrill MA, Lim IA, Shea MA, Schulman H, Hell JW. 2002. Regulation of calcium/calmodulin-dependent protein kinase II docking to $\mathrm{N}$-methyl-D-aspartate receptors by calcium/calmodulin and $\alpha$-actinin. J Biol Chem 277: 48441-48448.

Li W, Keifer J. 2009. BDNF-induced synaptic delivery of AMPAR subunits is differentially dependent on NMDA receptors and requires ERK. Neurobiol Learn Mem 91: 243-249.

Li G, Laabich A, Liu LO, Xue J, Cooper NG. 2001. Molecular cloning and sequence analyses of calcium/calmodulin-dependent protein kinase II from fetal and adult human brain. Sequence analyses of human brain calcium/calmodulin-dependent protein kinase II. Mol Biol Rep 28: $35-41$.

Lisman JE, Zhabotinsky AM. 2001. A model of synaptic memory: a CaMKII/ PP1 switch that potentiates transmission by organizing an AMPA receptor anchoring assembly. Neuron 31: 191-201.

Lisman J, Yasuda R, Raghavachari S. 2012. Mechanisms of CaMKII action in long-term potentiation. Nat Rev Neurosci 13: 169-182.

Liu YL, Zhou LJ, Hu NW, Xu JT, Wu CY, Zhang T, Li YY, Liu XG. 2007. Tumor necrosis factor- $\alpha$ induces long-term potentiation of C-fiber evoked field potentials in spinal dorsal horn in rats with nerve injury: the role of NF-к B, JNK and p38 MAPK. Neuropharmacology 52: 708-715.

Lledo PM, Hjelmstad GO, Mukherji S, Soderling TR, Malenka RC, Nicoll RA. 1995. Calcium/calmodulin-dependent kinase II and long-term potentiation enhance synaptic transmission by the same mechanism. Proc Natl Acad Sci 92: 11175-11179.

Makhinson M, Chotiner JK, Watson JB, O’Dell TJ. 1999. Adenylyl cyclase activation modulates activity-dependent changes in synaptic strength and $\mathrm{Ca}^{2+} /$ calmodulin-dependent kinase II autophosphorylation. J Neurosci 19: 2500-2510.
Malenka RC. 1991. The role of postsynaptic calcium in the induction of long-term potentiation. Mol Neurobiol 5: 289-295.

Malinow R, Schulman H, Tsien RW. 1989. Inhibition of postsynaptic PKC or CaMKII blocks induction but not expression of LTP. Science 245: 862-866.

McGlade-McCulloh E, Yamamoto H, Tan SE, Brickey DA, Soderling TR. 1993. Phosphorylation and regulation of glutamate receptors by calcium/calmodulin-dependent protein kinase II. Nature 362: $640-642$.

Meyer T, Hanson PI, Stryer L, Schulman H. 1992. Calmodulin trapping by calcium-calmodulin-dependent protein kinase. Science 256: $1199-1202$.

Morris EP, Török K. 2001. Oligomeric structure of $\alpha$-calmodulin-dependent protein kinase II. J Mol Biol 308: 1-8.

Murakoshi H, Wang H, Yasuda R. 2011. Local, persistent activation of Rho GTPases during plasticity of single dendritic spines. Nature 472: 100-104.

Ochiishi T, Yamauchi T, Terashima T. 1998. Regional differences between the immunohistochemical distribution of $\mathrm{Ca}^{2+} /$ calmodulindependent protein kinase II $\alpha$ and $\beta$ isoforms in the brainstem of the rat. Brain Res 790: $129-140$.

Oh MC, Derkach VA, Guire ES, Soderling TR. 2006. Extrasynaptic membrane trafficking regulated by GluR1 serine 845 phosphorylation primes AMPA receptors for long-term potentiation. J Biol Chem 281: $752-758$

Okamoto K, Bosch M, Hayashi Y. 2009. The roles of CaMKII and F-actin in the structural plasticity of dendritic spines: a potential molecular identity of a synaptic tag? Physiology 24: 357-366.

Otmakhov N, Griffith LC, Lisman JE. 1997. Postsynaptic inhibitors of calcium/calmodulin-dependent protein kinase type II block induction but not maintenance of pairing-induced long-term potentiation. $J$ Neurosci 17: 5357-5365.

Otmakhov N, Khibnik L, Otmakhova N, Carpenter S, Riahi S, Asrican B, Lisman J. 2004a. Forskolin-induced LTP in the CA1 hippocampal region is NMDA receptor dependent. J Neurophysiol 91: 1955-1962.

Otmakhov N, Tao-Cheng JH, Carpenter S, Asrican B, Dosemeci A, Reese TS, Lisman J. 2004b. Persistent accumulation of calcium/calmodulindependent protein kinase II in dendritic spines after induction of NMDA receptor-dependent chemical long-term potentiation. J Neurosci 24: 9324-9331.

Ouyang Y, Kantor D, Harris KM, Schuman EM, Kennedy MB. 1997. Visualization of the distribution of autophosphorylated calcium/ calmodulin-dependent protein kinase II after tetanic stimulation in the CA1 area of the hippocampus. J Neurosci 17: 5416-5427.

Pettit DL, Perlman S, Malinow R. 1994. Potentiated transmission and prevention of further LTP by increased CaMKII activity in postsynaptic hippocampal slice neurons. Science 266: 1881-1885.

Pi HJ, Otmakhov N, El Gaamouch F, Lemelin D, De Koninck P, Lisman J. 2010. CaMKII control of spine size and synaptic strength: role of phosphorylation states and nonenzymatic action. Proc Natl Acad Sci 107: $14437-14442$.

Poulsen DJ, Standing D, Bullshields K, Spencer K, Micevych PE, Babcock AM. 2007. Overexpression of hippocampal $\mathrm{Ca}^{2+} /$ calmodulindependent protein kinase II improves spatial memory. J Neurosci Res 85: $735-739$.

Raab-Graham KF, Haddick PCG, Jan YN, Jan LY. 2006. Activity- and mTOR-dependent suppression of Kv1.1 channel mRNA translation in dendrites. Science 314: 144-148.

Radwanska K, Medvedev NI, Pereira GS, Engmann O, Thiede N, Moraes MFD, Villers A, Irvine EE, Maunganidze NS, Pyza EM, et al. 2011. Mechanism for long-term memory formation when synaptic strengthening is impaired. Proc Natl Acad Sci 108: 18471-18475.

Rellos P, Pike ACW, Niesen FH, Salah E, Lee WH, von Delft F, Knapp S. 2010. Structure of the CaMKIII/calmodulin complex reveals the molecular mechanism of CaMKII kinase activation. PLoS Biol 8: e1000426.

Rich RC, Schulman H. 1998. Substrate-directed function of calmodulin in autophosphorylation of $\mathrm{Ca}^{2+} /$ calmodulin-dependent protein kinase II. J Biol Chem 273: 28424-28429.

Rose J, Jin SX, Craig AM. 2009. Heterosynaptic molecular dynamics: locally induced propagating synaptic accumulation of CaM kinase II. Neuron 61: $351-358$.

Sanhueza M, Lisman J. 2013. The CaMKII/NMDAR complex as a molecular memory. Mol Brain 6: 10 .

Sanhueza M, Fernandez-Villalobos G, Stein IS, Kasumova G, Zhang P, Bayer KU, Otmakhov N, Hell JW, Lisman J. 2011. Role of the CaMKII/ NMDA receptor complex in the maintenance of synaptic strength. $J$ Neurosci 31: 9170-9178.

Schulman H, Hanson PI. 1993. Multifunctional $\mathrm{Ca}^{2+} /$ calmodulindependent protein kinase. Neurochem Res 18: 65-77.

Shen K, Meyer T. 1999. Dynamic control of CaMKII translocation and localization in hippocampal neurons by NMDA receptor stimulation. Science 284: 162-166. 
Shen K, Teruel MN, Connor JH, Shenolikar S, Meyer T. 2000. Molecular memory by reversible translocation of calcium/calmodulin-dependent protein kinase II. Nat Neurosci 3: 881-886.

Shi SH, Hayashi Y, Petralia RS, Zaman SH, Wenthold RJ, Svoboda K, Malinow R. 1999. Rapid spine delivery and redistribution of AMPA receptors after synaptic NMDA receptor activation. Science 284: $1811-1816$.

Silva AJ, Paylor R, Wehner JM, Tonegawa S. 1992a. Impaired spatial learning in $\alpha$-calcium-calmodulin kinase II mutant mice. Science 257: 206-211.

Silva AJ, Stevens CF, Tonegawa S, Wang Y. 1992b. Deficient hippocampal long-term potentiation in $\alpha$-calcium-calmodulin kinase II mutant mice. Science 257: 201-206.

Strack S, Colbran RJ. 1998. Autophosphorylation-dependent targeting of calcium/calmodulin-dependent protein kinase II by the NR2B subunit of the N-methyl-D-aspartate receptor. J Biol Chem 273: 20689-20692.

Uhlén S, Wikberg JE. 1988. Relationship between forskolin and calcium-calmodulin stimulation of rat cerebral cortex adenylate cyclase: enzyme activation modulates substrate (MgATP) affinity. Pharmacol Toxicol 63: 90-95.

Villers A, Godaux E, Ris L. 2012. Long-lasting LTP requires neither repeated trains for its induction nor protein synthesis for its development. PLoS One 7: e40823.
Wei F, Vadakkan KI, Toyoda H, Wu LJ, Zhao MG, Xu H, Shum FWF, Jia YH, Zhuo M. 2006. Calcium calmodulin-stimulated adenylyl cyclases contribute to activation of extracellular signal-regulated kinase in spinal dorsal horn neurons in adult rats and mice. J Neurosci 26: $851-861$.

Wheeler DG, Barrett CF, Groth RD, Safa P, Tsien RW. 2008. CaMKII locally encodes L-type channel activity to signal to nuclear CREB in excitation-transcription coupling. J Cell Biol 183: 849-863.

Wu GY, Cline HT. 1998. Stabilization of dendritic arbor structure in vivo by CaMKII. Science 279: 222-226.

Yamagata Y, Kobayashi S, Umeda T, Inoue A, Sakagami H, Fukaya M, Watanabe M, Hatanaka N, Totsuka M, Yagi T, et al. 2009. Kinase-dead knock-in mouse reveals an essential role of kinase activity of $\mathrm{Ca}^{2+} /$ calmodulin-dependent protein kinase II $\alpha$ in dendritic spine enlargement, long-term potentiation, and learning. J Neurosci 29: 7607-7618.

Zou DJ, Cline HT. 1999. Postsynaptic calcium/calmodulin-dependent protein kinase II is required to limit elaboration of presynaptic and postsynaptic neuronal arbors. J Neurosci 19: 8909-8918.

Received June 3, 2014; accepted in revised form July 28, 2014. 


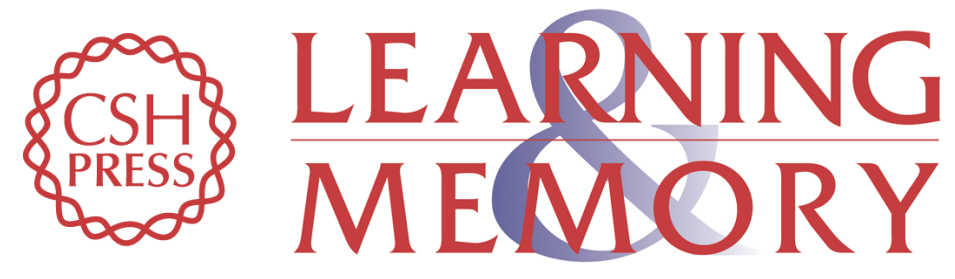

\section{Long-term potentiation can be induced in the CA1 region of hippocampus in the absence of $\alpha$ CaMKII T286-autophosphorylation}

Agnès Villers, Karl Peter Giese and Laurence Ris

Learn. Mem. 2014, 21:

Access the most recent version at doi:10.1101//m.035972.114

References This article cites 92 articles, 43 of which can be accessed free at: http://learnmem.cshlp.org/content/21/11/616.full.html\#ref-list-1

Creative This article is distributed exclusively by Cold Spring Harbor Laboratory Press for the Commons first 12 months after the full-issue publication date (see

License http://learnmem.cshlp.org/site/misc/terms.xhtml). After 12 months, it is available under a Creative Commons License (Attribution-NonCommercial 4.0 International), as described at http://creativecommons.org/licenses/by-nc/4.0/.

Email Alerting Receive free email alerts when new articles cite this article - sign up in the box at the Service top right corner of the article or click here. 